Original Research Article

\title{
A survey on the knowledge, attitude, and practices about antibiotic usage and resistance among homeopathic general practitioners
}

\author{
Yogesh B. Magar, Rajesh S. Hiray*, Jyoti B. Gadhade, Balasaheb B. Ghongane
}

Department of Pharmacology, B. J. Government Medical College, Pune, Maharashtra, India

Received: 30 September 2018 Accepted: 12 October 2018

\section{*Correspondence to: \\ Dr. Rajesh S. Hiray, \\ Email: rajesh.hiray@gmail.com}

Copyright: (C) the author(s), publisher and licensee Medip Academy. This is an openaccess article distributed under the terms of the Creative Commons Attribution NonCommercial License, which permits unrestricted noncommercial use, distribution, and reproduction in any medium, provided the original work is properly cited.

\begin{abstract}
Background: Antimicrobial resistance(AMR) is an urgent and serious global health problem, demanding considerable attention from health care providers(HCPs) all over the world. The threat is progressing rapidly and intensifying with time. Therefore study was conducted to assess the knowledge, attitude and practices of Homeopathic HCPs about antibiotic usage and resistance(ABR).

Methods: Cross-sectional, observational study. The data was collected from 75 Homeopathic HCPs practicing in Maharashtra with prior informed consent. Questionnaire based study whose responses were assessed by using five point Likert scale and analysed by using appropriate descriptive statistics.

Results: 68(90.67\%) respondents agreed that antibiotics are overused in India and $70(93.33 \%)$ of them facing ABR in their daily practices. Only $62(82.7 \%)$ of them were aware of the fact that bacteria are not responsible for causing colds and flu. 33(44\%) believe that skipping one or two doses of antibiotic does not contribute to ABR. Only 23(30.67\%) knew drug schedule H correctly. $22(29.33 \%)$ opined that antibiotics should be discontinued if patient develops mild gastrointestinal side effects. Only 28(37.33\%) reads patient information leaflet(PIL) and counsel patients accordingly. 28(38.67\%) feel that they don't have enough sources of antibiotic information and 35(46.67\%) find it difficult to select appropriate antibiotic.

Conclusions: Most of HCPs were aware of rising issue antibiotic resistance. However, their knowledge, attitude and practices were found to be a matter of some concern. Educational intervention can be introduced to bring about behaviour changes regarding rational antibiotics prescribing. Government should take initiative against overt antibiotic promotional advertisements and to curb over the counter(OTC) sell of antibiotics.
\end{abstract}

Keywords: Antibiotic resistance, Homeopathy HCPs, Over the counter, Rational prescribing

\section{INTRODUCTION}

Antimicrobial resistance(AMR) is the ability of a microorganism to resist the effects of medication which are previously used to treat them. It is on rise nowadays and possesses a hazard for the entire healthcare service system. It is an urgent and serious global health problem, demanding considerable attention from health care professionals all over the world. The major chunk of the problem persists in the developing countries. India tops in the irrational and indiscriminate use of antimicrobials. ${ }^{1}$ The threat is progressive rapidly and intensifying with the time. In 2011, on World Health Day, WHO set the theme as "Combat Antimicrobial Resistance: No Action Today, No Cure Tomorrow". ${ }^{2}$ This shows the importance of the issue of antibiotic resistance. It is important to think about various approaches, to meet the challenges and to tackle the problem. It is necessary to undertake campaigns among the general population as well as among the health care 
personnel about antibiotic resistance and its consequences and regarding the methods which can control its development as well as spread. ${ }^{3}$ One of the important causes leading to antibiotic resistance is irrational practices of healthcare professionals and indiscriminate use of antibiotics. ${ }^{4}$ Unnecessary and overprescribing is widely prevalent. ${ }^{5}$ It is basically driven by patient demand, uncertainty about diagnosis, and time pressure on clinicians. One of the best ways to control resistance is rational use of antibiotic. ${ }^{6}$ Various studies have shown the inability of the physicians in creating awareness and providing adequate education to the general population regarding antibiotic usage. ${ }^{7}$

India, being the country with high infectious disease burden, antibiotics are the most widely and frequently prescribed drugs accounting for the alarming increase in AMR. ${ }^{8}$ The irrational prescription practices by clinicians are mainly governed by the "more drug better doctor" beliefs of patients. Free unchecked over the counter (OTC) availability of antibiotics for human, animal and industrial consumption, self medication, lack of knowledge, unjustified demand for antibiotics prescription and unawareness regarding antibiotic resistance are other factors that add up to the current degrading situation. The general practitioners belong to a group of medical professionals and their knowledge, attitude and behavior in relation to public usage of antibiotics can greatly impact in the future on antibiotic-related issues.

To curb this emerging horizon of AMR a national antibiotic policy was developed, national surveillance database for antibiotic use was established and national centre for disease control (NCDC) is designated as the focal point for AMR in the country. ${ }^{9,10}$ Though these wellstructured interventional strategies are still in infancy, it has started yielding positive changes at national and community level. However, something more specific and directed needs to be done at individual level that influences health related behaviour. While knowledge plays a significant role in providing an insight about the problems faced, it is the beliefs and attitude that matters most in directing the desired behavioural change. Ultimate aim of all these interventions is to bring out attitude and behavioural changes at the very grass-root level. A strong foundation is of utmost importance for a durable construction hence we need to strengthen the base of the health care system by nipping the problem of resistance in the bud itself. So, this study was undertaken among homeopathic general practitioners practicing homeopathic medicine since long from various districts of Maharashtra, India in order to assess their knowledge and attitude concerning antibiotic resistance and self-reported practices which are related to antibiotic usage.

\section{METHODS}

A cross- sectional, observational questionnaire based study was carried out after approval from the Institutional Ethics Committee (BJGMC/IEC/ Pharmac/ND-Dept
1217262-262) was obtained before initiating the study. It was conducted for 2 months of period from 01st Oct 2017 to 31st Nov 2017 at B.J. Government medical college in Pune.

Questionnaire based cross sectional survey was undertaken among general homeopathic practitioners practicing in different regions of Maharashtra. The questionnaire was validated by subject experts for its content and relevance prior to the start of the study. Then questionnaire was distributed to 75 general homeopathic practitioners of Maharashtra who were doing one year MUHS certified "Certificate Course in Modern Pharmacology". They were asked to complete the questionnaire anonymously. Informed consent was taken from the participants.

\section{Analysis of data}

All responses collected were analysed for various parameters like knowledge, attitude and practices about antibiotic usage and resistance among Homeopathic healthcare providers by using questionnaires as mentioned in case record form.

Homeopathic practitioners who were practicing since long in different regions of Maharashtra who have enrolled for MUHS officiated one year certificate course in modern pharmacology was given case record form after taking informed consent. Anonymity of participants was maintained. Students from batch 2016-17 who have finished their one year of course and students pursuing i.e. batch 2017-18 were enrolled for the study.

They were given self-developed questionnaires consisting of closed ended and few open-ended types of questionnaires. Total of 33 questions were provided to participants. Data record form consisted of questions of yes/no, true/false, strongly agree/strongly disagree scale and always/usually/never type.

Responses were recorded in Microsoft excel 2010 and analysed by using appropriate descriptive statistical tests.

\section{RESULTS}

The age range of the practitioners ranged from $55.1 \pm 6.175$ years (mean $\pm \mathrm{SD}$ ). Male predominance was found over females. The mean clinical practice of the general practitioners ranged from $29.32 \pm 6.342$ years. (mean \pm SD). $68(90.67 \%)$ respondents agreed that antibiotics are overused in India and $70(93.33 \%)$ of them facing antibiotic resistance (ABR) in their daily practices. 35 $(46.67 \%)$ find it difficult to select appropriate antibiotic. Only $62(82.7 \%)$ of them were aware of the fact that bacteria are not responsible for causing colds and flu. 33 (44\%) believe that skipping one or two doses of antibiotic does not contribute to ABR (Table 1). Only 23 (30.67\%) knew drug schedule H correctly. 22 (29.33\%) opined that antibiotics should be discontinued if patient develops mild 
gastrointestinal side effects. Only $28(37.33 \%)$ read patient information leaflet (PIL) and counsel patients accordingly.
$28(38.67 \%)$ feel that they don't have enough sources of antibiotic information and (Table 1).

Table 1: Evaluation of knowledge, attitude about antibiotic resistance in homeopathy GPs.

\begin{tabular}{|lllllll|}
\hline Question & St. agree & Agree & Neutral & Disagree & St. disagree & Total \\
\hline Antibiotics are overused & $36(48 \%)$ & $32(42.67 \%)$ & $4(5.33 \%)$ & $2(2.67 \%)$ & $1(1.33 \%)$ & 75 \\
\hline Difficult to select correct antibiotic & $4(5.33 \%)$ & $31(41.33 \%)$ & $22(29.33 \%)$ & $15(20 \%)$ & $3(4 \%)$ & 75 \\
\hline $\begin{array}{l}\text { Antimicrobial does not cause } \\
\text { damage when no indicated }\end{array}$ & $8(10.67 \%)$ & $16(21.33 \%)$ & $3(4 \%)$ & $35(46.67 \%)$ & $13(17.33 \%)$ & 75 \\
\hline $\begin{array}{l}\text { Antimicrobial resistance is a } \\
\text { problem in daily practice }\end{array}$ & $24(32 \%)$ & $46(61.33 \%)$ & $3(4 \%)$ & $2(2.67 \%)$ & 0 & 75 \\
\hline Antibiotics when patients have cold & 0 & $4(5.33 \%)$ & $9(12 \%)$ & $42(56 \%)$ & $20(26.67 \%)$ & 75 \\
\hline $\begin{array}{l}\text { Antibiotics when patients have } \\
\text { fever }\end{array}$ & $2(2.67 \%)$ & $21(28 \%)$ & $5(6.67 \%)$ & $39(52 \%)$ & $8(10.67 \%)$ & 75 \\
\hline $\begin{array}{l}\text { Skipping 1/2 doses does not } \\
\text { contribute to antibiotic resistance }\end{array}$ & $4(5.33 \%)$ & $29(38.67 \%)$ & $5(6.67 \%)$ & $32(42.67 \%)$ & $5(6.67 \%)$ & 75 \\
\hline Antibiotics are safe drugs & $2(2.67 \%)$ & $4(5.33 \%)$ & $4(5.33 \%)$ & $37(49.33 \%)$ & $28(37.33 \%)$ & 75 \\
\hline $\begin{array}{l}\text { Antibiotic in patients with cough } \\
\text { and sore throat }\end{array}$ & $9(12 \%)$ & $10(13.33 \%)$ & $32(42.67 \%)$ & $7(9.33 \%)$ & $17(22.67 \%)$ & 75 \\
\hline $\begin{array}{l}\text { Follows instructions mentioned in } \\
\text { package insert/ Patient information } \\
\text { leaflet }\end{array}$ & $28(37.33 \%)$ & $19(25.33 \%)$ & $19(25.33 \%)$ & $6(8 \%)$ & $3(4 \%)$ & 75 \\
\hline $\begin{array}{l}\text { Chloramphenicol eye drop in } \\
\text { patient of mild conjunctivitis }\end{array}$ & $3(4 \%)$ & $11(14.67 \%)$ & $25(33.33 \%)$ & $6(8 \%)$ & $30(40 \%)$ & 75 \\
\hline
\end{tabular}

Table 2: Evaluation of practices about antibiotic resistance in homeopathy GPs.

\begin{tabular}{|lllll|}
\hline Question & Yes & No & $\begin{array}{l}\text { Sometimes/ } \\
\text { uncertain }\end{array}$ & Total \\
\hline Prescribing antibiotics & $74(98.67 \%)$ & $1(1.33 \%)$ & 0 & 75 \\
\hline Sources of information about antibiotics when needed & $46(61.33 \%)$ & $29(38.67 \%)$ & 0 & 75 \\
\hline Sending body fluids for Antibiotic C/S test & $46(61.33 \%)$ & $10(13.33 \%)$ & $19(25.33 \%)$ & 75 \\
\hline Prescribing antibiotics after C/S test & $35(46.67 \%)$ & $8(10.67 \%)$ & $32(42.67 \%)$ & 75 \\
\hline $\begin{array}{l}\text { Counsel patient to clean hands before and after application of } \\
\text { topical antibiotics }\end{array}$ & $65(86.67 \%)$ & $4(5.33 \%)$ & $6(8 \%)$ & 75 \\
\hline Stoppage of Antibiotic if patient develops mild GI side effect & $22(29.33 \%)$ & $53(70.67 \%)$ & 0 & 75 \\
\hline
\end{tabular}

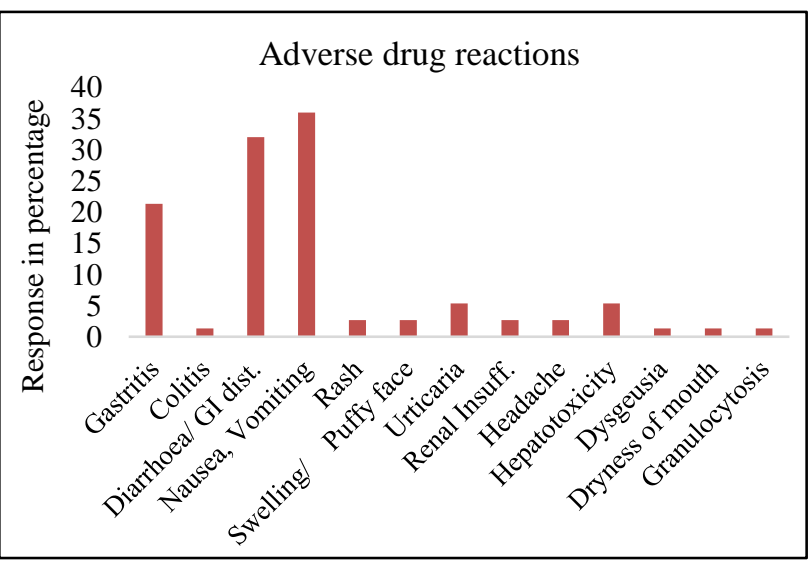

Figure 1: Response of the practitioners to adverse drug reactions of azithromycin.

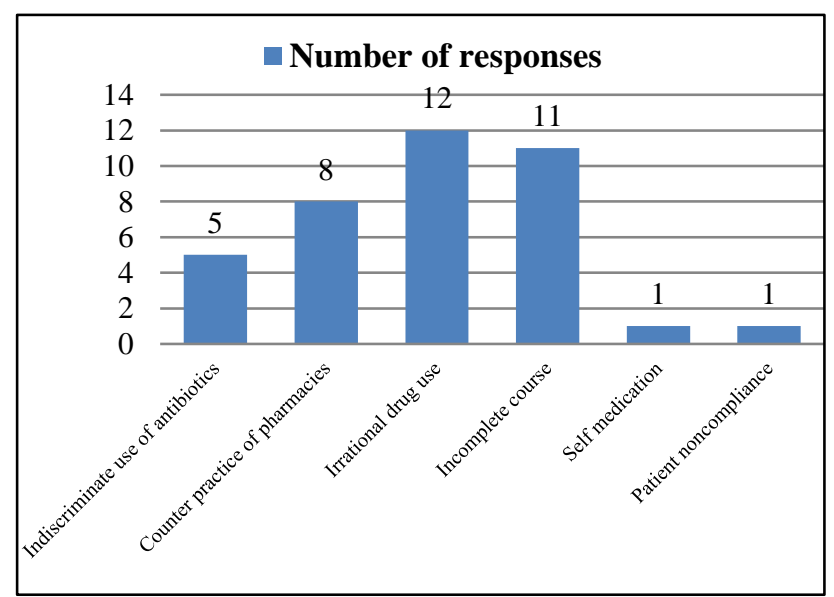

Figure 2: Reasons of antibiotic resistance by GPs. 
Almost $99 \%$ GPs prescribe antibiotics in their clinical practice but only $61 \%$ sends body fluids like blood, urine, stool sample for culture sensitivity and out of them only 47\% GPs prescribe antibiotic after verifying C/S report (Table 2). $87 \%$ of GPs counsel their patients about hygienic requirements for topical application of Antibiotics like using clean hands and application on dry, non-moist surface (Table 2).

The response rate to the question of sources of information on antibiotics was only $28 \%$. The homeopathy general practitioners find CME $(9.33 \%)$, Medical Bulletins $(5.33 \%)$, Medical Representatives $(5.33 \%)$, Journals (2.66\%), Conferences (2.66\%), Modern Pharmacology Certified Course $(2.66 \%)$ as sources of information about antibiotics. 27 practitioners believed that nausea and vomiting is the most common adverse drug reaction seen with Azithromycin. 24 of these practitioners were of the opinion that diarrhoea and gastrointestinal disturbance were common adverse events recorded with Azithromycin. 16 practitioners said that gastritis was the most common adverse reaction noted with Azithromycin. 4 of the practitioners agreed with hepatotoxicity. Remaining few practitioners were of the opinion that the most common adverse drug reactions were rash, urticarial, dysgeusia, dryness of mouth, granulocytosis, puffy face and colitis (Figure 1). 12 practitioners among the 75 opined that irrational drug usage is the most common cause of antibiotic drug resistance. 11 of them said that incomplete course of the antibiotics is the most common cause. 8 of the practitioners blamed the counter practice of pharmacists as the most common cause of AMR. Only few said that non-compliance of the patient or self medication could be one of the many causes of AMR (Figure 2).

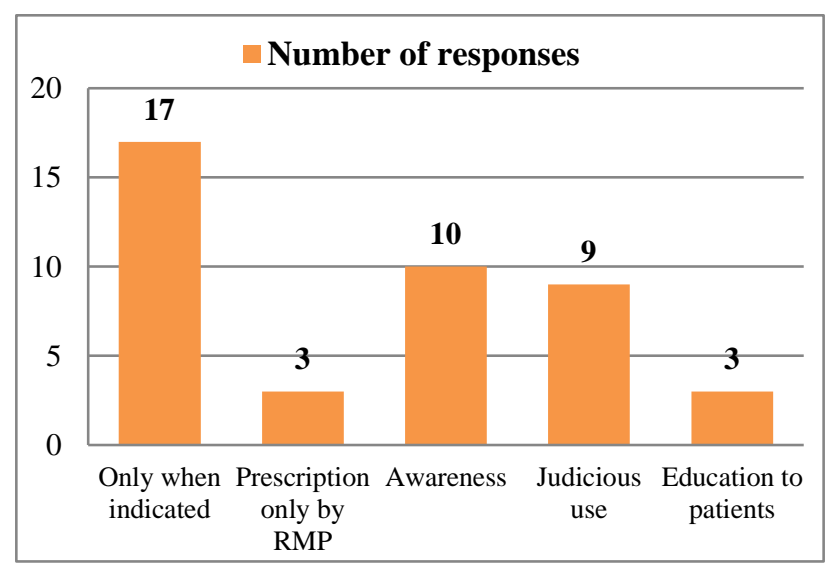

Figure 3: Solutions to antibiotic resistance by GPs.

To tackle these causes of ABR, 17 practitioners suggested that drugs should only be given when indicated. 10 of the total practitioners said that awareness should be the main moto for tackling the AMR. 9 respondents were of the view that AMR can be minimised with the help of judicious use of antibiotics. Only 3 of them stated that prescription should be given by registered medical practitioner only. 3 other practitioners believed that education to the patients can help in combating the issue of AMR (Figure 3).

\section{DISCUSSION}

This study surveyed the knowledge, attitude and practice towards antibiotic use and ABR in homeopathic general practitioners. Our findings showed how the practitioners had a fair good knowledge about the role of antibiotics and related adverse reactions and the causes leading to antimicrobial resistance. The study suggests that there is an urgent need of awareness and educational interventions to tackle the problem of AMR.

All the participants responded to the questionnaire. So, the response was $100 \% .98 .67 \%$ of the homeopathic general practitioners prescribed antibiotics in their daily practice. $48 \%$ of the practitioners were aware of the indiscriminate use of antibiotics in hospitals in India. $61.33 \%$ experienced $\mathrm{ABR}$ in their daily practice which reflects the seriousness of the problem. $52 \%$ of the respondents strongly believed that antibiotics don't help in making the patient better in fever. Majority of the general practitioners (49.33\%) opined that antibiotics are not safe drugs and hence should not be used commonly in daily practice. This is similar to Gupta RK et al, study. ${ }^{11} 89.33 \%$ of the practitioners insisted on full completion of full course of treatment. This shows their knowledge and attitude towards AMR. 53\% of practitioners considered about rationality before prescribing an antibiotic. This is similar to the study conducted by Khanna $\mathrm{S}$ et al. ${ }^{12} 83 \%$ of the participants were knowledgeable of the fact that bacteria were not responsible for causing cold and flu which is much more than Padmanabha TS et al, and Afzal et al, study. ${ }^{13}$ Only $17 \%$ of practitioners considered prescription of antibiotics for cough and sore throat unnecessary. $84 \%$ of the practitioners ask their patients to check for expiry date of the antibiotics before using them. $47 \%$ of the practitioners considered prescribing antibiotics after culture sensitivity test. Interactive learning between pharmacology and microbiology helps in rational antimicrobial prescribing behaviour with infection control. Since antibiotic resistance among pathogenic microorganisms is a matter of worldwide concern, the prescribers should know the microorganism sensitivity pattern before prescribing it. ${ }^{14}$

Simple measures like hand washing in the control of resistance should be encouraged and its practice should be started at an earlier stage of the medical profession. ${ }^{13}$

The attitude of the study participants with regards to antibiotic use and resistance was found to be satisfactory. Previous studies have shown that about $60 \%$ and more of their participants believed that antibiotics should be prescribed during cold of viral etiology. ${ }^{15}$ Such wrong and blind beliefs may lead to inappropriate antibiotic consumption, which in turn result in the bacterial resistance because of irrational approach. ${ }^{16}$ Among the positive attitude, majority agreed for the need of campaign to create awareness among the population as well as health 
care professional. To combat growing problem of antibiotic resistance, spreading awareness was also reported by Mahajan M et al, Gupta RK et al, and Sharma $\mathrm{S}$ et al. ${ }^{17,18}$

Education interventions using clinical problems which depicts the hazardous effects of antibiotic resistance, can be used to improve as well as make them alert on present and future consequences, which encourages the correct usage of antibiotics by avoiding the resistance conquering the whole world. ${ }^{19}$

Health professionals are key to any country's health status, hence it's important to take necessary steps for developing proper knowledge, attitude and practices among them regarding antibiotic resistance. ${ }^{12}$

\section{CONCLUSION}

Most of HCPs were aware of rising issue antibiotic resistance. However, their knowledge, attitude and practices were found to be a matter of some concern. Educational intervention can be introduced to bring about behaviour changes regarding rational antibiotics prescribing. Government should take initiative against overt antibiotic promotional advertisements and to curb over the counter(OTC) sell of antibiotics.

Funding: No funding sources

Conflict of interest: None declared

Ethical approval: The study was approved by the Institutional Ethics Committee (BJGMC/IEC) Pharmac/ND-Dept 1217262-262)

\section{REFERENCES}

1. Kumar SG, Adithan C, Harish BN, Sujatha S, Roy G, Malini A. Antimicrobial resistance in India: a review. J Nat Sci Biol Med. 2013;4:286-9.

2. World Health Day 2011-Antibiotic resistance: No action today, no cure tomorrow. Available at: http://www.who.int/mediacentre/news/statements/20 11/whd_20110407/en/ind ex.html [Cited 4 Dec 2017]

3. Simpson SA, Wood F, Butler CC. General practitioners perceptions of antimicrobial resistance: a qualitative study. Journal of Antimicrobial Chemotherapy. 2007;59:292-6.

4. Minen MT, Duquaine D, Marx MA, Weiss D. A survey of knowledge, attitudes, and beliefs of medical students concerning antimicrobial use and resistance. Microb Drug Resist. 2010;16(4):285-9.

5. Sintchenko V, Iredell JR, Gilbert GL, Coiera E. What do physicians think about evidence-based antibiotic use in critical care? A survey of Australian intensivists and infectious disease practitioners. Inter Med J. 2001;31:462-9.

6. Zafar SN, Syed R, Waqar S, Zubairi AJ, Vaqar T, Shaikh M, Yousaf W, Shahid S, Saleem S. Selfmedication amongst university students of Karachi: prevalence, knowledge and attitudes. J Pak Med Associa. 2008;58(4):214.

7. Guerra CM, Pereira CAP, Neto ARV, Cardo DM, Correa L. Physicians perceptions, beliefs, attitudes, and knowledge concerning antimicrobial resistance in a Brazilian teaching hospital. Infect Control Hosp Epidemiol. 2007;28:1411-4.

8. World health organization. Prevention and containment of antimicrobial resistance. Available at: http://www.ino.searo.who.int/LinkFiles/Other_Conte nt_WHD11-Seminar Presentation-WRpdf. [Cited 4 Dec 2017]

9. Huang Y, Gu J, Zhang M, Ren Z, Yang W, Chen Y. Knowledge, attitude and practice of antibiotics: a questionnaire study among 2500 Chinese students. BMC Medical Education. 2013;13:163.

10. Tarao SM, Nulla P, Zingpi M, Agatha G. A study on the knowledge, attitude, perceptions and practices of antibiotic usage and resistance among the medical students of JNIMS, Imphal, Manipur. Journal of Evidence Based Medicine and Healthcare. 2015;2:5262-8.

11. Gupta RK, Singh P, Rani R, Kumari R, Langer B, Gupta R. Antibiotic use: evaluating knowledge, attitude and practices among medical students in a sub Himalayan state. Int $\mathbf{J}$ Basic Clin Pharmacol 2017;6:2516-21.

12. Khanna S, Pratap S, Singh DK, Tutu S, Lakhani P, Dixit RK. A Survey on the Knowledge, Attitude, and Practices about anti-biotic resistance among general practitioners of Northern India. World J Pharm Sci. 2016;4(6):449-53.

13. Padmanabha TS, Nandini T, Manu G, Savka MK. Knowledge, attitude and practices of antibiotic usage among the medical undergraduates of a tertiary care teaching hospital: an observational cross-sectional study. Int J Basic Clin Pharmacol. 2016 Dec;5(6):2432-7.

14. Davey P, Garner S. Professional education on antimicrobial prescribing: a report from the Specialist Advisory Committee on Antimicrobial Resistance (SACAR) Professional Education Subgroup. J Antimicrobial Chemotherapy. 2007;60(1):i27-32.

15. Azevedo MM, Pinheiro C, Yaphe J, Baltazar F. Portuguese students' knowledge of antibiotics: a cross-sectional study of secondary school and university students in Braga. BMC Public Health. 2009;9:359.

16. Steinberg I. Clinical choices of antibiotics: judging judicious use. The Am J Managed Care. 2000;6(23):S1178-88.

17. Mahajan M, Dughgaonkar S, Deshmukh S. A questionnaire based survey on the knowledge, attitude and practises about antimicrobial resistance and usage among the second year MBBS students of a teaching tertiary care hospital in central India. International Journal of Pharmacological Research. 2014;4:175-9.

18. Sharma S, Jayakumar D, Palappallil DS, Kesavan KP. Knowledge, attitude and practices of antibiotic usage 
and resistance among the second year MBBS

Students. Int J Basic Clin Pharmacol. 2016;5:899-903.

19. Wester CW, Durairaj L, Evans AT, Schwartz DN,

Husain S, Martinez E. Antibiotic Resistance - A

Survey of Physician Perceptions. Arch Intern Med. 2002;162:2210-6.
Cite this article as: Magar YB, Hiray RS, Gadhade $\mathrm{JB}$, Ghongane BB. A survey on the knowledge, attitude, and practices about antibiotic usage and resistance among homeopathic general practitioners. Int J Basic Clin Pharmacol 2018;7:2112-21. 


\section{Annexure 1}

\section{APPENDIX 1: - CASE RECORD FORM}

Date-____ $/ 2017$

\section{CASE RECORD FORM}

TITILE OF PROJECT: “A survey on the knowledge, attitude, and practices about antibiotic usage and resistance among homeopathic general practitioners.”

I'm carrying out a study on "A survey on the knowledge, attitude, and practices about antibiotic usage and resistance among homeopathic general practitioners" You are part of a representative sample for my study. I would be very grateful if you would be so kind to take part in my study answering the following questions. Please answer them spontaneously and openly. Leave blank those you are not able to answer. Your answers will of course remain completely anonymous and will be only statistically reported and not singularly. As a principal investigator I take full responsibility for this.

\section{QUESTIONNAIRE:}

\section{Demographic data:}

Name-(optional) Age...yrs Sex-

Designation-..... In Clinical Practice (Since)yrs

Address-

\begin{tabular}{|c|c|c|}
\hline Sr No & Question & Answer \\
\hline 1 & Do you prescribe antibiotics? & $\begin{array}{l}\square \text { Yes } \\
\square \text { No }\end{array}$ \\
\hline 2 & $\begin{array}{l}\text { How frequently do you prescribe antibiotics in your } \\
\text { clinic/hospital? }\end{array}$ & $\begin{array}{l}\square \text { More than once a day } \\
\square \text { Once a day } \\
\square \text { 3-5 times per week } \\
\square \text { 1-2 times per week } \\
\square \text { Less than once a week }\end{array}$ \\
\hline 3 & $\begin{array}{l}\text { Do you think you have enough sources of information about } \\
\text { antibiotics when you need it? }\end{array}$ & $\begin{array}{l}\text { Yes } \\
\text { No, should be more sources of } \\
\text { information (please specify which sources } \\
\text { do you think would be useful): }\end{array}$ \\
\hline 4 & Antibiotics are overused in clinics/hospitals in India & $\begin{array}{l}\square \text { Strongly agree } \\
\square \text { Agree } \\
\square \text { Neutral } \\
\square \text { Disagree } \\
\square \text { Strongly disagree }\end{array}$ \\
\hline 5 & I believe it is difficult to select the correct antibiotic & $\begin{array}{l}\square \text { Strongly agree } \\
\square \text { Agree } \\
\square \text { Neutral } \\
\square \text { Disagree } \\
\square \text { Strongly disagree }\end{array}$ \\
\hline 6 & $\begin{array}{l}\text { Do you think efficacy of antibiotic is better if they are of } \\
\text { recent origin and costlier }\end{array}$ & $\begin{array}{l}\square \text { Strongly agree } \\
\square \text { Agree } \\
\square \text { Neutral } \\
\square \text { Disagree } \\
\square \text { Strongly disagree }\end{array}$ \\
\hline
\end{tabular}




\begin{tabular}{|c|c|c|}
\hline 7 & $\begin{array}{l}\text { When I decide which antibiotic to use, my selection is more } \\
\text { affected by the expiration date/availability than the cause of } \\
\text { the infection. }\end{array}$ & $\begin{array}{l}\square \text { Strongly agree } \\
\square \text { Agree } \\
\square \text { Neutral } \\
\square \text { Disagree } \\
\square \text { Strongly disagree }\end{array}$ \\
\hline 8 & $\begin{array}{l}\text { Do you believe that prescribing antimicrobial does not cause } \\
\text { damage when patients do not need them? }\end{array}$ & $\begin{array}{l}\square \text { Strongly agree } \\
\square \text { Agree } \\
\square \text { Neutral } \\
\square \text { Disagree } \\
\square \text { Strongly disagree } \\
\end{array}$ \\
\hline 9 & $\begin{array}{l}\text { Do you think that currently antimicrobial resistance is a } \\
\text { problem in your daily practice? }\end{array}$ & $\begin{array}{l}\square \text { Strongly agree } \\
\square \text { Agree } \\
\square \text { Neutral } \\
\square \text { Disagree } \\
\square \text { Strongly disagree }\end{array}$ \\
\hline 10 & $\begin{array}{l}\text { Which one of the following antibiotics may be safe during } \\
\text { pregnancy? }\end{array}$ & $\begin{array}{l}\square \text { Amoxicillin } \\
\square \text { Ciprofloxacin } \\
\square \text { Gentamicin } \\
\square \text { Clindamycin }\end{array}$ \\
\hline 11 & $\begin{array}{l}\text { Antimicrobial resistance means that if they are taken too } \\
\text { often, antimicrobials are less likely to work in the future? }\end{array}$ & $\begin{array}{l}\square \text { True } \\
\square \text { False } \\
\square \text { Uncertain }\end{array}$ \\
\hline 12 & Bacteria cause common cold and influenza? & $\begin{array}{l}\square \text { True } \\
\square \text { False } \\
\square \text { Uncertain }\end{array}$ \\
\hline 13 & $\begin{array}{l}\text { Do you think that ineffective treatment with growing problem } \\
\text { of resistance can occur due to indiscriminate and injudicious } \\
\text { antimicrobial use? }\end{array}$ & $\begin{array}{l}\square \text { True } \\
\square \text { False } \\
\square \text { Uncertain } \\
\end{array}$ \\
\hline 14 & $\begin{array}{l}\text { Do you prescribe antibiotics to prevent getting a more serious } \\
\text { illness, when patients have a cold? }\end{array}$ & $\begin{array}{l}\square \text { Strongly agree } \\
\square \text { Agree } \\
\square \text { Neutral } \\
\square \text { Disagree } \\
\square \text { Strongly disagree }\end{array}$ \\
\hline 15 & $\begin{array}{l}\text { When patients get fever, antibiotics help them to get better } \\
\text { more quickly? }\end{array}$ & $\begin{array}{l}\square \text { Strongly agree } \\
\square \text { Agree } \\
\square \text { Neutral } \\
\square \text { Disagree } \\
\square \text { Strongly disagree }\end{array}$ \\
\hline 16 & $\begin{array}{l}\text { Skipping one or two doses does not contribute to the } \\
\text { development of antibiotic resistance }\end{array}$ & $\begin{array}{l}\square \text { Strongly agree } \\
\square \text { Agree } \\
\square \text { Neutral } \\
\square \text { Disagree } \\
\square \text { Strongly disagree }\end{array}$ \\
\hline 17 & Antibiotics are safe drugs, hence they can be commonly used & $\begin{array}{l}\square \text { Strongly agree } \\
\square \text { Agree } \\
\square \text { Neutral } \\
\square \text { Disagree } \\
\square \text { Strongly disagree }\end{array}$ \\
\hline \multirow{3}{*}{18} & \multicolumn{2}{|c|}{ The Doctor prescribes a course of antibiotic for a patient. After taking $2-3$ doses he starts feeling better. } \\
\hline & 1) He should stop taking the further treatment? & $\begin{array}{l}\square \text { Always } \\
\square \text { Usually } \\
\square \text { Sometimes } \\
\square \text { Seldom } \\
\square \text { Never }\end{array}$ \\
\hline & 2) He should complete the full course of treatment? & $\begin{array}{l}\square \text { Always } \\
\square \text { Usually } \\
\square \text { Sometimes } \\
\square \text { Seldom } \\
\square \text { Never } \\
\end{array}$ \\
\hline
\end{tabular}




\begin{tabular}{|c|c|c|}
\hline 19 & Do you check the rationality before starting an antibiotic? & $\begin{array}{l}\square \text { Always } \\
\square \text { Usually } \\
\square \text { Sometimes } \\
\square \text { Seldom } \\
\square \text { Never }\end{array}$ \\
\hline 20 & $\begin{array}{l}\text { Do you ask patients to check the expiry date of the antibiotic } \\
\text { before using it? }\end{array}$ & $\begin{array}{l}\square \text { Always } \\
\square \text { Usually } \\
\square \text { Sometimes } \\
\square \text { Seldom } \\
\square \text { Never }\end{array}$ \\
\hline 21 & $\begin{array}{l}\text { Do you prefer to prescribe antibiotic when patients have } \\
\text { cough and sore throat? }\end{array}$ & $\begin{array}{l}\square \text { Always } \\
\square \text { Usually } \\
\square \text { Sometimes } \\
\square \text { Seldom } \\
\square \text { Never }\end{array}$ \\
\hline 22 & $\begin{array}{l}\text { Is it necessary to carry out large scale antibiotics campaign } \\
\text { promotion to create awareness among the population and } \\
\text { health care professional }\end{array}$ & $\begin{array}{l}\square \text { Always } \\
\square \text { Usually } \\
\square \text { Sometimes } \\
\square \text { Seldom } \\
\square \text { Never }\end{array}$ \\
\hline 23 & Do you know antibiotic culture sensitivity $(\mathrm{C} / \mathrm{S})$ test? & $\begin{array}{l}\square \text { Yes } \\
\square \text { No }\end{array}$ \\
\hline a) & If yes, do you send the sample of body fluids for C/S test? & $\begin{array}{l}\square \text { Yes } \\
\square \text { No } \\
\square \text { Sometimes } \\
\end{array}$ \\
\hline 24 & Do you prescribe antibiotic after doing culture sensitivity test? & $\begin{array}{l}\square \text { Yes } \\
\square \text { No } \\
\square \text { Sometimes }\end{array}$ \\
\hline 25 & $\begin{array}{l}\text { Do you prefer prescribing low cost generic drug over branded } \\
\text { drugs? }\end{array}$ & $\begin{array}{l}\square \text { Yes } \\
\square \text { No } \\
\square \text { Sometimes } \\
\end{array}$ \\
\hline 26 & $\begin{array}{l}\text { How commonly do you use Fixed Dose Combinations } \\
\text { antibiotics? }\end{array}$ & $\begin{array}{l}\square \text { Always } \\
\square \text { Usually } \\
\square \text { Sometimes } \\
\square \text { Seldom } \\
\square \text { Never }\end{array}$ \\
\hline 27 & $\begin{array}{l}\text { While prescribing topical antibiotics do you tell patient to } \\
\text { clean hands before and after application at site? }\end{array}$ & $\begin{array}{l}\square \text { Yes } \\
\square \text { No } \\
\square \text { Sometimes }\end{array}$ \\
\hline 28 & $\begin{array}{l}\text { Do you prescribe Chloramphenicol eye drop for patient of } \\
\text { mild conjunctivitis? }\end{array}$ & $\begin{array}{l}\square \text { Always } \\
\square \text { Usually } \\
\square \text { Sometimes } \\
\square \text { Seldom } \\
\square \text { Never }\end{array}$ \\
\hline 29 & $\begin{array}{l}\text { Do you read, follow and tell or counsel patients to obey } \\
\text { instructions mentioned in package insert/ Patient information } \\
\text { leaflet? }\end{array}$ & $\begin{array}{l}\text { Always } \\
\square \text { Usually } \\
\square \text { Sometimes } \\
\square \text { Seldom } \\
\square \text { Never }\end{array}$ \\
\hline 30 & $\begin{array}{l}\text { Do you of the opinion that antibiotic should be stopped if } \\
\text { patient develops mild gastrointestinal side effect? }\end{array}$ & $\begin{array}{l}\text { Yes } \\
\square \text { No }\end{array}$ \\
\hline 31 & Enlist most common adverse effects of Azithromycin? & $\begin{array}{l}\ldots, \ldots, \ldots \\
\ldots \ldots \ldots\end{array}$ \\
\hline
\end{tabular}

\section{Q. 32. Which of the following is true for schedule $H$ drugs?}

a) To be sold by retail on the prescription of registered medical practitioner only. 
b) It is dangerous to take this preparation except in accordance with the medical advice. Not to be sold by retail without prescription of a registered medical practitioner.

c) It is dangerous to take this preparation except under medical supervision.

d) I have no idea.

Q. 33. What do you think is the cause of antibiotic resistance? Can you suggest few solutions for same to tackle the growing problem of antimicrobial resistance?

Thank you very much for filling the survey.

Signature and Name of Investigator:

(Dr. Yogesh B. Magar) 